\title{
NP Internal Tonosyntax: High Tone and Quantifier Conditions
}

\author{
Ronald P. Schaefer \& Francis O. Egbokhare*
}

\begin{abstract}
This paper applies a model of tonosyntax designed for the Dogon languages to Emai, another language of West Africa that belongs to the Edoid group. The Dogon model aligns with and diverges from the tonosyntax of Emai. In Dogon noun phrases, an adnominal controller prompts a $\{\mathrm{L}\}$ (low) tone overlay onto the lexical tone of a left-adjacent target. Numerals, quantifiers and discourse markers fail as controllers. In Emai, most adnominals except cardinal numerals and discourse markers trigger a $\{\mathrm{H}\}$ overlay on a left-adjacent head or other adnominal. Emai varies from Dogon on two additional counts. Emai quantifiers prompt tonal overlay. In addition, right edge lexical $/ \mathrm{H} /$ constrains $\{\mathrm{H}\}$ overlay. We conclude by positing a potential relation between low $\{\mathrm{L}\}$ vs high $\{\mathrm{H}\}$ overlay and Clements and Railland's (2008) lax vs tense prosody types.
\end{abstract}

Keywords. tonosyntax; replacive tone; reference restrictors; prosody types; Emai

1. Introduction. Heath and McPherson (2013) as well as McPherson (2014) and McPherson and Heath (2016) advance a model of tonosyntax. It stipulates that lexical tone is completely replaced by a grammatically conditioned tonal overlay. This model is illustrated by melodic patterns involving noun phrase internal elements in the Dogon languages of West Africa.

2. Dogon tonosyntax. In the Dogon canonical instance, adnominals are controllers or noncontrollers and nouns are targets. An adnominal controller in Dogon prompts a $\{\mathrm{L}\}$ (low) tone overlay onto the lexical tone melody of a left-adjacent target. In Tommo So, the lexical /LH/ on noun isé 'dog' becomes \{LL\} after a low overlay prompted by adnominal adjective gém 'black.' isé 'dog' isè gém 'black dog'

Constraining tonal overlay is reference restriction. Heath and McPherson $(2013,276)$ identify reference restriction as the partitioning of an open nominal set into eligible and ineligible members.

"Reference restriction is the basis for tonosyntactic control: NP-internal modifiers that belong to stem classes or to syntactic or functional categories that include and exclude specific individuals of a reference set, and no other modifiers, control tone overlays on (at least) the noun."

In the Dogon noun phrase, adnominal controllers are reference restrictors. They prompt a $\{\mathrm{L}\}$ overlay. Adnominal non-controllers are not reference restrictors; they are inert for purposes of $\{\mathrm{L}\}$ overlay. Lexical and phrasal illustration from Ben Tey with adjectives $b a ́ r^{n} \grave{a}-w^{n} b \grave{e}$ 'red' and

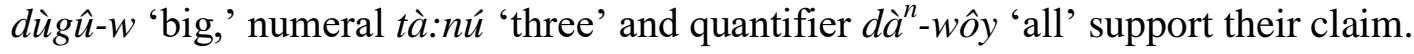

\footnotetext{
* Data incorporated in this paper derive from sponsorship by the National Science Foundation, (BNS \#9011338 and SBR \#9409552), the Department of State (CUAP ASJY 1333), and the National Endowment for the Humanities (PD-50004-06). Authors: Southern Illinois University Edwardsville (rschaef@ siue.edu) and University of Ibadan (foegbokhare@yahoo.com).
} 


\begin{tabular}{|c|c|c|c|c|}
\hline$k u ́ r^{n} \grave{u}$ & 'stone' & /HL/ & màygórò 'mango' & /LHL/ \\
\hline kùr ${ }^{n} \grave{u}$ & $b a r^{n} \grave{a}-w^{n} \quad b \grave{e}$ & 'red stones' & màygòrò dùg $\hat{u}-w$ & 'big mango' \\
\hline$k u r^{n} \grave{u}$ & tà:nú & 'three stones' & màygórò tà:nú & 'three mangoes' \\
\hline$k u r^{n} \grave{u}$ & $d \grave{a}^{n}-w \hat{o} y$ & 'all stones' & màygórò dăn${ }^{n}-w \hat{o} y$ & 'all mangoes' \\
\hline
\end{tabular}

3. Emai tonosyntax. Our purpose in this paper is to examine the Heath and McPherson model as it relates to NP internal tonosyntax in Emai. Emai is a recently documented Edoid language of south central Nigeria that falls within West Benue Congo in the Niger Congo phylum (Elugbe 1973, Elugbe 1989, Williamson and Blench 2000). It employs lexical and grammatical tone in the context of a relatively rigid SVO word order type (Schaefer and Egbokhare 2007, Schaefer and Egbokbhare 2017).

Emai aligns with and diverges from Dogon tonosyntax. In both languages, overall syntacticsemantic systematicity prevails in the assignment of tone to noun phrase constituents.

Emai executes a $\{\mathrm{H}\}$ (high) overlay pattern in contrast to the $\{\mathrm{L}\}$ overlay of Dogon. An adnominal controller in Emai prompts a $\{\mathrm{H}\}$ tone overlay onto the lexical tone melody of a (leftadjacent) target. Following Heath and McPherson, our initial hypothesis for Emai is that adnominal controllers are reference restrictors, while adnominal non-controllers are not reference restrictors. Controllers should then prompt a $\{\mathrm{H}\}$ overlay, whereas non-controllers should be inert to $\{\mathrm{H}\}$ overlay.

In Emai, adnominals can be a lexical item or a syntactic phrase. In the canonical instance, overlay prompted by an adnominal affects the lexical melody of a head noun like /LL/ ìwè 'house' or /HL/ éwè 'goat.' Regardless of pre-overlay lexical tone on these head nouns, their post-overlay tone is $\{\mathrm{HH}\}$.

\begin{tabular}{|c|c|c|c|c|}
\hline demonstrative & $\begin{array}{l}\text { nà } \\
\text { áìn } \\
\text { nói }\end{array}$ & $\begin{array}{l}\text { íwé } \\
\text { íwé } \\
\text { íwé }\end{array}$ & $\begin{array}{l}\text { nà } \\
\text { áìn } \\
\text { nóì }\end{array}$ & $\begin{array}{l}\text { 'this house' } \\
\text { 'that house' } \\
\text { 'the next house' }\end{array}$ \\
\hline kindred & $\begin{array}{l}\text { énìná } \\
\text { élìyó } \\
\text { é-dàn }\end{array}$ & $\begin{array}{l}\text { éwé } \\
\text { éwé } \\
\text { éwé }\end{array}$ & $\begin{array}{l}\text { énìná } \\
\text { élìyó } \\
\text { édàn }\end{array}$ & $\begin{array}{l}\text { 'goats of this kind' } \\
\text { 'goats of that kind' } \\
\text { 'goat of a different kind' }\end{array}$ \\
\hline $\begin{array}{l}\text { adjective } \\
\text { with linker } l i\end{array}$ & kéré & $\underline{e} w e ́$ li & kéré & 'small goat' \\
\hline $\begin{array}{l}\text { relative clause } \\
\text { with linker } l i\end{array}$ & & \multicolumn{2}{|c|}{ éwé lí ójé shén-ì } & 'goat that Oje sold' \\
\hline $\begin{array}{l}\text { possessum } \\
\text { with linker ísì }\end{array}$ & & \multicolumn{2}{|c|}{ éwé ísì òjè } & 'goat of Oje's' \\
\hline
\end{tabular}

Each of these controllers in the canonical instance is a reference restrictor. It includes and excludes set members from the category house or goat. Non-canonical adjacency relations within an Emai noun phrase, e.g. adnominal vis-à-vis adnominal, are similarly impacted by tonal overlay. A $\{\mathrm{H}\}$ tone is overlain on the lexical melody of left-adjacent adnominals like possessor òjè and its /LL/ lexical melody relative to a following demonstrative. Demonstrative nà 'this,' when it immediately follows possessor òjè, prompts an overlay on lexical/LL/ resulting in $\{\mathrm{HH}\}$ ójé. Dogon has an equivalent $\{\mathrm{L}\}$ overlay. 
Adnominals that are not reference restrictors do not trigger tonal overlay on a target. They are

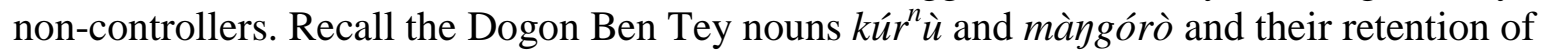
lexical melody patterns with a numeral or quantifier adnominal:

$\begin{array}{lllll}\text { kúr }{ }^{n} \grave{u} & \text { 'stone' } & \text { /HL/ } & \text { màygórò } & \text { 'mango' /LHL/ } \\ k^{\prime} r^{n} \grave{u} & \text { tà:nú } & \text { 'three stones' } & \text { màygórò tà:nú } & \text { 'three mangoes' } \\ \text { kúr } r^{n} \grave{u} & d \grave{a}^{n} \text {-wôy } & \text { 'all stones' } & \text { màygórò dàn }{ }^{n} \text {-wôy } & \text { 'all mangoes' }\end{array}$

In Emai, non-controllers include cardinal numerals as well as discourse functional forms. Neither cardinal form èvá 'two' nor èélè 'four' prompts a $\{\mathrm{H}\}$ tonal overlay on lexical/LL/ éwè. A similar retention of lexical tone occurs when a discourse marker like ôkpá 'alone' follows a noun. This much is consistent with the non-controllers proposed for Dogon.

$\begin{array}{llllll}\text { cardinal numeral } & \text { èvá } & \text { 'two' } & \text { éwè } & \text { èvá 'two goats' } \\ & \text { èélè } & \text { 'four' } & \text { éwè } & \text { èélè 'four goats' } \\ \text { discourse } & \underline{o} k p a ́ & \text { 'alone' } & \underline{e} w e ̀ ~ & \text { ôkpá 'a goat alone' }\end{array}$

4. Divergence of Emai from Dogon. Emai overlay patterns diverge from Dogon in two key respects. The first concerns quantifiers and the second pertains to lexical melody constraints on tonal overlay. While cardinal numerals in Dogon and Emai are non-controllers, quantifiers in Dogon are non-controllers as well. However in Emai quantifiers serve as controllers.

Emai quantifiers control replacive tone. Whether existential or universal, they prompt a $\{\mathrm{H}\}$ overlay on their target, which in the canonical instance is a noun.

\begin{tabular}{llll} 
existential quantifier & $\underline{o} s \grave{ }$ & $\underline{e} w e ́$ ósò & 'a certain goat, some goat' \\
& $\underline{o} v b e ̀ e$ & $\underline{e} w e ́$ óvbèe & 'other/another goat' \\
\multirow{3}{*}{ universal quantifier } & èrèmé & $\underline{e} w e ́$ èrèmé & 'all goats' \\
& $\underline{o} d \underline{d o o ́ d e ́ ~}$ & íkpósó òdóòddé 'each of the women'
\end{tabular}

Existential quantifiers, at least, appear to restrict membership in a class. $\underline{o} s o ̀$ refers to a certain goat that is known to the speaker. This includes any goat known to the speaker and excludes any goat not known to the speaker. The situational quantifier óvbèe functions in much the same way. It includes another goat and excludes this goat, for example.

Universal quantifiers are more problematic, given the definition of reference restriction in Heath and McPherson and the proposed relationship between reference restriction and controller of tonal overlay. Universal quantifiers in Emai are not reference restrictors; they include all goats in a referential set or each goat, but they do not exclude any goat, by definition. Since universal quantifiers are not reference restrictors, they should not be controllers of a tonal overlay process according to Heath and McPherson.

That Emai universal quantifiers are controllers was shown by the tonal overlay on /LL/ $\underline{e} w e ̀$ 'goat' prompted by èrèmé 'all' and òdóoòdé 'each' in the examples above. Perhaps as Heath and McPherson maintain about borderline cases such as definite articles and numeral 'one,' 
language-specific factors may be operating in Emai. Exactly what those factors might be, however, remains unresolved and worthy of further investigation.

Emai divergence from Dogon extends to another issue. Dogon replaces lexical tone melodies with tonal overlays in an absolute fashion. Relative to a lexical melody, $\{\mathrm{L}\}$ overlay in Dogon operates without restriction. Lexical melody is disregarded and erased completely.

Emai does not replace lexical tone melodies completely with tonal overlay. It defers to lexical $/ \mathrm{H} /$, especially but not exclusively right edge $/ \mathrm{H} /$. Emai $\{\mathrm{H}\}$ overlay is relative.

Emai not only relies on $\{\mathrm{H}\}$ overlay but also constrains overlay with lexical /H/. Important in this regard is that any lexical /L/ that precedes a right edge high tone also remains unaffected by $\{\mathrm{H}\}$ tone overlay, as with /LLH/ àkàsán 'maize pudding' and /LH/ ùgín 'basket' when followed by an adnominal. Each retains its left edge low tone and any following low tone up to a right edge $/ \mathrm{H} /$.

àkàsán 'maize pudding'

àkàsán lì ògbèré 'plentiful maize pudding'

ùgín 'basket' àkàsán nói 'the next maize pudding' ùgín isì òjè 'basket of Oje's' ùgín élìyó 'basket of that kind

In fact, the constraining power of lexical $/ \mathrm{H} /$ is not limited to right edge high tone. A lexical $/ \mathrm{H} /$ in any non-left edge position within a lexical melody will limit $\{\mathrm{H}\}$ overlay to its left. Such is the case with /LHL/ àmágò 'mango' relative to a following adnominal controller.

$\begin{array}{llll}\text { àmágò mango' } & \text { àmágó } & \text { ísì òjè } & \text { 'mango of Oje’s' } \\ & \text { àmágó élìyó } & \text { 'mango of that kind' }\end{array}$

5. Conclusion. We conclude with a note about a possible relation between the contrasting replacive processes of Dogon ( $\{\mathrm{L}\}$ overlay) and Emai $(\{\mathrm{H}\}$ overlay) and the distinct prosody types identified in Clements and Railland (2008). Clements and Railland allocate a language to one or another prosody type based on the final prosodic mark of its polar question: "tense" with high pitch/rising pitch vs "lax" with non-high pitch/falling pitch.

The lax prosody type is prominent in the western sector of Africa's Sudanic belt, where Dogon languages are spoken. Indeed, lax appears to be the prosody type of the Dogon languages Bunage (Heath 2017a) and Yorno So (Heath 2017c).

The tense prosody type is prominent elsewhere. Emai reflects this type. It employs a higher pitch register for polar questions. And with rhetorical questions, as shown below, it adds sentence final $\{\mathrm{H}\}$ to a lexical low.

(1) ólí ómòhè ò $\underline{o} \quad$ è ólí émàèé?

the man SC CONT eat the food

'The man is eating the food is he?'

Our hypothesis is that the low $\{\mathrm{L}\}$ vs high $\{\mathrm{H}\}$ overlay pattern in Dogon and Emai is but a further instance of the respective prosody types "lax" vs "tense". If so, we should not find low $\{\mathrm{L}\}$ overlay with tense languages or high $\{\mathrm{H}\}$ overlay with lax languages. Hopefully, future research will clarify this matter and allow us to better understand how tonal systems, despite their diversity, might actually reflect a few basic types. 


\section{References}

Elugbe, Ben. 1973. A comparative Edo phonology. Ph.D dissertation, University of Ibadan, Nigeria.

Elugbe, Ben. 1989. Comparative Edoid: Phonology and lexicon. Port Harcourt: University of Port Harcourt Press.

Heath, Jeffrey. 2015. Dogon non-compositional constructional tonosyntax. Journal of African Languages and Linguistics 36 (2). 233-252. https://doi.org/10.1515/jall-2015-0010.

Heath, Jeffrey. 2017a. A grammar of Bunoge (Dogon, Mali). Language Description Heritage Library, Max Planck Gesellshaft.

Heath, Jeffrey. 2017b. A grammar of Najamba (Dogon, Mali). Language Description Heritage Library, Max Planck Gesellshaft.

Heath, Jeffrey. 2017c. A grammar of Yorno So (Toro So subgroup of Dogon, Mali). Language Description Heritage Library, Max Planck Gesellshaft.

Heath, Jeffrey \& Laura McPherson. 2013. Tonosyntax and reference restriction in Dogon NPs. Language 89 (2). 265-296. https://doi.org/10.1353/lan.2013.0020.

Clements, George N. \& Annie Rialland. 2008. Africa as a phonological area. In Bernd Heine \& Derek Nurse (eds.). A linguistic geography of Africa. 36-85. New York: Cambridge University Press.

McPherson, Laura. 2014. Replacive grammatical tone in the Dogon languages. Ph.D. dissertation, Department of Linguistics, UCLA.

McPherson, Laura \& Jeffrey Heath. 2016. Phrasal grammatical tone in the Dogon languages: The role of constraint interaction. Natural Language and Linguistic Theory 34. 593-639. https://doi.org/10.1007/s11049-015-9309-5.

Schaefer, Ronald P. \& Francis O. Egbokhare. 2007. A dictionary of Emai: An Edoid language of Nigeria. Köln: Rüdiger Köppe Verlag.

Schaefer, Ronald P. \& Francis O. Egbokhare. 2017. A grammar of Emai. [Mouton Grammar Library Series]. Berlin: Mouton de Gruyter.

Williamson, Kay \& Roger Blench. 2000. Niger Congo. In Bernd Heine \& Derek Nurse (eds.), African languages: An introduction. 11-42. New York: Cambridge University Press. 